\title{
Differential effects of cortisol and 11-deoxycorticosterone on ion transport protein mRNA levels in gills of two euryhaline teleosts, Mozambique tilapia (Oreochromis mossambicus) and striped bass (Morone saxatilis)
}

\author{
Pia Kiilerich ${ }^{1}$, Christian K Tipsmark ${ }^{1,2}$, Russell J Borski ${ }^{\mathbf{2}}$ and Steffen S Madsen ${ }^{\mathbf{1}}$ \\ ${ }^{1}$ Institute of Biology, University of Southern Denmark, Campusvej 55, DK-5230 Odense M, Denmark \\ ${ }^{2}$ Department of Biology, North Carolina State University, Raleigh, North Carolina 27695-7617, USA \\ (Correspondence should be addressed to S S Madsen; Email: steffen@biology.sdu.dk) \\ C K Tipsmark is now at Department of Biological Sciences, University of Arkansas, Fayetteville, Arkansas 72701, USA
}

\begin{abstract}
The role of cortisol as the only corticosteroid in fish osmoregulation has recently been challenged with the discovery of a mineralocorticoid-like hormone, 11-deoxycorticosterone (DOC), and necessitates new studies of the endocrinology of osmoregulation in fish. Using an in vitro gill explant incubation approach, DOC-mediated regulation of selected osmoregulatory target genes in the gill was investigated and compared with that of cortisol in two euryhaline teleosts, Mozambique tilapia (Oreochromis mossambicus) and striped bass (Morone saxatilis). The effects were tested in gills from both fresh water (FW)- and seawater (SW)-acclimated fish. Both cortisol and DOC caused an up-regulation of the $\mathrm{Na}^{+}, \mathrm{K}^{+}$-ATPase $\alpha 1$ subunit in SW-acclimated tilapia but had no effect in FW-acclimated fish. Cortisol conferred an increase in $\mathrm{Na}^{+}, \mathrm{K}^{+}, 2 \mathrm{Cl}^{-}$cotransporter (NKCC) isoform $1 a$ transcript levels in FW- and SW-acclimated tilapia, whereas
\end{abstract}

DOC had a stimulatory effect only in SW-acclimated fish. Cortisol had no effect on NKCC isoform $1 \mathrm{~b}$ mRNA levels at both salinities, while DOC stimulated this isoform in $\mathrm{SW}$-acclimated fish. In striped bass, cortisol conferred an up-regulation of $\mathrm{Na}^{+}, \mathrm{K}^{+}$-ATPase $\alpha 1$ and NKCC transcript levels in FW- and SW-acclimated fish, whereas DOC resulted in down-regulation of these transcripts in FW-acclimated fish. It was also found that both corticosteroids may rapidly $(30 \mathrm{~min})$ alter the mitogen-activated protein kinase signalling pathway in gill, inducing phosphorylation of extracellular signalregulated kinase 1 (ERK1) and ERK2 in a salinity-dependent manner. The study shows a disparate organisation of corticosteroid signalling mechanisms involved in ion regulation in the two species and adds new evidence to a role of DOC as a mineralocorticoid hormone in teleosts.

Journal of Endocrinology (2011) 209, 115-126

\section{Introduction}

It is generally accepted that the corticosteroid hormone, cortisol, plays a central osmoregulatory role during acclimation to both hyper- and hyposaline environments in teleosts (McCormick 2001, Sakamoto et al. 2001). However, the recent discovery of a potential mineralocorticoid receptor (MR) with high affinity for the mineralocorticoid hormone 11-deoxycorticosterone (DOC) and two glucocorticoid receptor (GR) isoforms has expanded the extent through which the corticosteroid family of hormones and receptors may work to regulate hydromineral balance in teleosts. Cortisol binds with high affinity to the three cytosolic corticosteroid receptors in fish, GR1, GR2 and MR, whereas DOC specifically binds to the MR (see Prunet et al. (2006)). The receptor type(s) through which cortisol exerts its osmoregulatory effects and the role of DOC signalling are still not firmly established. Once associated with hormone, the classical cytosolic corticosteroid receptor translocates to the cell nucleus, where target gene transcription is modulated via a well-established slow-acting genomic pathway. However, rapid effects of corticosteroids have also been reported (Borski 2000, Haller et al. 2008) and may occur through additional membrane-bound receptors and/or interaction with cytosolic signalling cascade pathways.

Numerous studies in many fish species from a variety of genera have shown that cortisol may stimulate the level of important ion transport proteins (mRNA, protein and activity) in the gill. The $\mathrm{Na}^{+}, \mathrm{K}^{+}$-ATPase and $\mathrm{Na}^{+}, \mathrm{K}^{+}, 2 \mathrm{Cl}^{-}$cotransporter (NKCC) are two examples of membrane proteins governing transport of $\mathrm{Na}^{+}$and $\mathrm{Cl}^{-}$ions across the gill epithelium against steep gradients between plasma and water. Accordingly, cortisol may regulate gill chloride cell differentiation and proliferation (reviewed by 
McCormick (2001) and Sakamoto et al. (2001)), thereby improving overall ion-translocation capacity. Some effects of cortisol were shown to be mediated by the GR, although a few recent reports point to a role for the MR as well (Sloman et al. 2001, Scott et al. 2005, Kiilerich et al. 2007, 2010). There may, however, be species-specific differences in the role of corticosteroids for the development of ion transport mechanisms in relation to the degree of euryhalinity.

In this study, we used two Perciform teleosts, the Mozambique tilapia (Oreochromis mossambicus) and the American striped bass (Morone saxatilis), as model species to evaluate corticosteroid effects on gill $\mathrm{Na}^{+}, \mathrm{K}^{+}$-ATPase and NKCC expression. Both species are highly euryhaline; however, their acclimation 'strategy' in molecular terms seems different when exposed to increasing salinity. The Mozambique tilapia develops the appropriate hypo-osmoregulatory mechanisms gradually when stimulated by increased salinity (Morgan et al. 1997, Uchida et al. 2000). Thus, the energy to build the appropriate mechanisms is only spent when needed. On the other hand, studies in striped bass have shown that this species have important hypoosmoregulatory mechanisms present (chloride cells and high levels of $\mathrm{Na}^{+}, \mathrm{K}^{+}$-ATPase) in the gill irrespective of salinity (Madsen et al. 1994, Tipsmark et al. 2004, 2007). In energetic terms, this must be viewed as a costly strategy. The different acclimation 'strategies' are also evident in the endocrine response when the two species are challenged with changing salinity. In tilapia, direct transfer from fresh water (FW)- to seawater (SW) results in drastically increased levels of plasma cortisol, and subsequently chloride cell number, NKCC1a and $\mathrm{Na}^{+}, \mathrm{K}^{+}$-ATPase mRNA, protein and activity levels in the gill (Assem \& Hanke 1981, Morgan et al. 1997, Hwang et al. 1998, Hiroi et al. 2008, Inokuchi et al. 2008). Accordingly, cortisol seems to be an important osmoregulatory hormone in tilapia, where it stimulates $\mathrm{Na}^{+}, \mathrm{K}^{+}$-ATPase activity and chloride cell proliferation and differentiation (Dangé 1986, McCormick 1990). In striped bass, there is little or no deviation in the above parameters when challenged by increased salinity (Madsen et al. 1994, Tipsmark et al. 2004, 2007), and the available evidence suggests that cortisol is not involved in salinity acclimation. Even though FW striped bass transferred to SW showed increased plasma cortisol and gill $\mathrm{Na}^{+}, \mathrm{K}^{+}$-ATPase activity (Madsen et al. 1994), similar changes were observed in fish sham-transferred to FW, suggesting that these changes are related to the handling stress of the animals rather than salinity per se (Madsen et al. 1994). Accordingly, cortisol has either no effect in vivo on gill $\mathrm{Na}^{+}, \mathrm{K}^{+}$-ATPase activity or $\alpha$-subunit mRNA or a slight stimulatory effect in vitro on gill $\alpha$-subunit mRNA in FW striped bass (Madsen et al. 2007). We therefore hypothesise that the different salinity acclimation strategies and the role of cortisol herein may be reflected in differential responses of the gill to corticosteroids. In order to test this, we used an in vitro gill explant incubation system to investigate the potential for cortisol- and DOC-mediated regulation of transcript levels of two selected target genes $\left(\mathrm{Na}^{+}, \mathrm{K}^{+}\right.$-ATPase and
NKCC) in relation to acclimation salinity of the two species. Transcriptional effects of steroids are classically considered as slow-acting effects. However, in order to test the possibility of rapid signalling effects, we also investigated the potential for regulatory effects of cortisol and DOC on the phosphorylation status (activation) of two members of the MAPK signalling cascade, extracellular signal-regulated kinase 1 (ERK1) and ERK2 in the two species. Activation of the MAPK pathway may have a central role in transducing osmosensory as well as endocrine signals in the gill (Madsen et al. 2007).

\section{Materials and Methods}

Fish: adult mixed sex tilapia (O. mossambicus) from Pamlico Aquaculture Field Laboratory (Aurora, NC, USA) and sexually immature, mixed sex, juvenile striped bass (M. saxatilis) obtained from FW ponds at the Edenton National Fish Hatchery (Edenton, NC, USA) were held at $12 \mathrm{~h}$ light: $12 \mathrm{~h}$ darkness at $22{ }^{\circ} \mathrm{C}$ and fed with pelleted feed made available ad libitum. Fish were held in 5001 tanks and fully acclimated to either recirculated, filtered FW or full strength SW. When sampled, fish were stunned by a blow to the head and bled from the tail. Gills were removed and placed in ice-cold Ringer's solution (final concentration in mol/l: $0 \cdot 14 \mathrm{NaCl}, 0 \cdot 015$ $\mathrm{NaHCO}_{3}, 0 \cdot 0025 \mathrm{KCl}, 0 \cdot 0015 \mathrm{CaCl}_{2}, 0 \cdot 001 \mathrm{KH}_{2} \mathrm{PO}_{4}, 0 \cdot 0008$ $\mathrm{MgSO}_{4}, 0 \cdot 01$ dextrose, 0.005 HEPES, $\mathrm{pH}$ 7.8; equilibrated with $99 \% \mathrm{O}_{2} / 1 \% \mathrm{CO}_{2}$ ) with the addition of penicillin and streptomycin (400 $000 \mathrm{IU} / \mathrm{l})$ until further dissected.

\section{In vitro gill incubation with corticosteroids and antagonists}

Gill blocks of two to three filament pairs were carefully dissected from the cartilage arch and incubated for $24 \mathrm{~h}$ in Falcon multi-well six-well plates with gentle shaking at room temperature with $2 \mathrm{ml}$ oxygenated $\left(99 \% \quad \mathrm{O}_{2} / 1 \% \mathrm{CO}_{2}\right)$ Ringer's solution containing hormones, antagonists or a combination (control: vehicle $(0 \cdot 003 \% \quad(\mathrm{v} / \mathrm{v})$ dimethyl sulfoxide (DMSO)); cortisol (F): cortisol-hemisuccinate $(10 \mu \mathrm{g} / \mathrm{ml}) ; \quad F+R U: F(10 \mu \mathrm{g} / \mathrm{ml})+\mathrm{RU} 486(20 \mu \mathrm{g} / \mathrm{ml})$; F+ Spi: F $(10 \mu \mathrm{g} / \mathrm{ml})+$ spironolactone $(20 \mu \mathrm{g} / \mathrm{ml})$; RU: RU486 $(20 \mu \mathrm{g} / \mathrm{ml})$; Spi: spironolactone $(20 \mu \mathrm{g} / \mathrm{ml})$; DOC $(10 \mu \mathrm{g} / \mathrm{ml}) ;$ DOC + Spi: DOC $(10 \mu \mathrm{g} / \mathrm{ml})+$ spironolactone $(20 \mu \mathrm{g} / \mathrm{ml}) ; 1 \cdot 0 \mathrm{~F}: \mathrm{F}(1 \mu \mathrm{g} / \mathrm{ml}) ; 0 \cdot 1 \mathrm{~F}: \mathrm{F}(0 \cdot 1 \mu \mathrm{g} / \mathrm{ml}) ; 1 \cdot 0$ DOC: DOC $(1 \mu \mathrm{g} / \mathrm{ml}) ; 0 \cdot 1$ DOC: DOC $(0 \cdot 1 \mu \mathrm{g} / \mathrm{ml})$. Cortisol-hemisuccinate sodium salt (Sigma-Aldrich) was dissolved in Ringer's solution, whereas DOC, RU486 and spironolactone (Sigma-Aldrich) were dissolved in DMSO. All wells were adjusted to equal DMSO load. After incubation, gill blocks were transferred to RNAlater (Ambion, Austin, TX, USA) and frozen at $-20{ }^{\circ} \mathrm{C}$ until RNA purification.

\section{$R N A$ purification, $c D N A$ synthesis and $q P C R$}

Total RNA was purified using GenElute Mammalian Total RNA kit (Sigma-Aldrich) according to the manufacturer's 
recommendations. RNA concentration and purity were determined by measuring A260/A280 (values between 2.06 and $2 \cdot 23)$. RNA $(1 \mu \mathrm{g})$ was DNase treated, reverse transcribed and subjected to semi-quantitative real-time PCR as described previously (Kiilerich et al. 2007). Reactions were carried out with $1 \mu \mathrm{l} \mathrm{cDNA}$ (corresponding to $20 \mathrm{ng}$ RNA), 5 pmol forward and reverse primer (Invitrogen), $12.5 \mu \mathrm{l}$ of Brilliant II SYBR green master mix (Stratagene, La Jolla, CA, USA) in a total volume of $25 \mu$ l. Cycling conditions were $95^{\circ} \mathrm{C}$ for $30 \mathrm{~s}, 60^{\circ} \mathrm{C}$ for $20 \mathrm{~s}$ and $72{ }^{\circ} \mathrm{C}$ for $10 \mathrm{~s}$ for 50 cycles. Melting curve analysis was routinely carried out for $30 \mathrm{~s}$ for each $1{ }^{\circ} \mathrm{C}$ interval from 60 to $95{ }^{\circ} \mathrm{C}$. Calculation of relative copy number for target and normalisation genes was carried out using the Pfaffl equation (Pfaffl 2001), $(1+\mathrm{Ea})^{-C_{\mathrm{t}}}$, where Ea is the amplification efficiency, and $C_{\mathrm{t}}$ is the threshold cycle number. Normalised values were obtained by dividing the relative copy number of the target to that of the normalisation gene, $18 \mathrm{~S}$ rRNA. The normalisation gene was not significantly affected by any treatment at any salinity, and the relative expression level did not differ between salinities in either tilapia or striped bass. Tilapia primer sequences and amplicon lengths are as follows (Genbank accession numbers in parenthesis): $18 \mathrm{~S}$ rRNA (AF497908) forward 5'-TATTGTGCCGCTAGAGGTGAA- $3^{\prime}$ and reverse $5^{\prime}$-CCTCCGACTTTCGTTCTTGA- $3^{\prime}$, $102 \mathrm{bp} ; \mathrm{Na}^{+}, \mathrm{K}^{+}$-ATPase $\alpha 1$ (U82549) forward $5^{\prime}$-GAAGCCATTGTGGTGGTT- $3^{\prime}$ and reverse 5'-TGTGGCAGTTGGCTCAGT-3', 136 bp; NKCC1a (AY513737) forward 5'-AAGACAAGAAGAGCCCGACAG-3' and reverse $5^{\prime}$-AGACATCCACTGTGCCCTTCC-3', $105 \mathrm{bp}$; and NKCC1b (AY513738) forward 5'-CCGCGTTTGGAATTAAATGTG-3' and reverse $5^{\prime}$-TCGGTGCATCACTGAGAGACA- $3^{\prime}$ mRNA sequence, $91 \mathrm{bp}$. Striped bass primer sequences and amplicon length are as follows: $\mathrm{Na}^{+}, \mathrm{K}^{+}$-ATPase based on the killifish $\mathrm{Na}^{+}, \mathrm{K}^{+}$-ATPase $\alpha 1$ sequence (AY057072) forward $5^{\prime}$-GGGGATGGTGTAAACGACTC- $3^{\prime}$ and reverse $5^{\prime}$-CAGGGTGTAGGCAATGGATTTCTTCA-3', 194 bp; NKCC1 based on the Dicentrarchus labrax NKCC1 (AY532638 - this sequence was previously used to design a northern blot probe for striped bass in Tipsmark et al. (2004)) forward 5'-CGCCTAAAGCCAAACACATT- $3^{\prime}$ and reverse $5^{\prime}$-CCTGGGAGGATAGCAAGTCA-3', 193 bp. Tilapia primers for $18 S$ rRNA were also used for striped bass normalisation. The specificity of the primers was assessed with melting curve analysis, showing only one single product for each primer set, and confirmed by agarose gel verification of correct amplicon size. The amplification efficiencies were $\mathrm{Na}^{+}, \mathrm{K}^{+}$-ATPase $\alpha 1$ : $100 \cdot 2 \%$, NKCC1a: 107·2\%, NKCC1b: 96·1\%, 18S: $107 \cdot 5 \%$ for tilapia; $\mathrm{Na}^{+}, \mathrm{K}^{+}$-ATPase: $98 \cdot 5 \%$, NKCC1: $86 \cdot 4$ and $18 \mathrm{~S}$ : $71 \%$ for striped bass.

\section{Cortisol and DOC effects on ERK-1 and -2 phosphorylation}

Gill blocks of two to four filament pairs were incubated in Ringer's solution with or without $10 \mu \mathrm{g} / \mathrm{ml}$ cortisol or DOC as described earlier for $30 \mathrm{~min}$. Initially, a time-course experiment (10, 20 and $30 \mathrm{~min}$ ) was conducted to determine the optimal incubation time for maximal ERK phosphorylation (activation), showing $30 \mathrm{~min}$ to be the optimal incubation time (data not shown). For western blotting, one gill block was sonicated in 100-120 $\mu 1$ NuPAGE LDS sample buffer (Invitrogen) with reducing agent for 15-20 s at $35 \%$ output (Fisher sonic dismembrator model 300, Fisher Scientific, Pittsburgh, PA, USA) and frozen at $-20^{\circ} \mathrm{C}$ until western blotting. Gel electrophoresis, blotting and immunological detection and quantification of dual phosphorylated (active) and total ERK1 and ERK2 by infrared imaging (Odyssey, LI-COR) were carried out as described previously (Madsen et al. 2007). In short, dual phosphorylated ERK $1 / 2$ was detected using a monoclonal mouse phospho-p44/42 mitogen-activated protein kinase (MAPK; Thr202/Tyr204) antibody from Cell Signaling (Beverly, MA, USA; dilution 1:2000). Total ERK $1 / 2$ was detected using a polyclonal rabbit anti-MAPK (sc-94; Santa Cruz Biotechnology, Santa Cruz, CA, USA; dilution 1:1000). Following washing, membranes were incubated for $1 \mathrm{~h}$ with goat anti-mouse and/or anti-rabbit secondary antibodies conjugated to Alexa IRDye 680 or IRDye $800 \mathrm{CW}$ (LI-COR). Phosphorylated and total ERK $1 / 2$ were detected on the same blot at 680 and $800 \mathrm{~nm}$ respectively. Active ERK1 and ERK2 were normalised to total ERK1 and ERK2 content.

\section{Statistical analysis}

Data in Figs 1-6 (mean \pm s.E.M., $n=6)$ were analysed using a repeated-measures one-way ANOVA followed by a StudentNewman-Keuls test in an all pairwise fashion. In Fig. 7, a two-way ANOVA was followed by a Bonferroni's-adjusted Fisher's LSD test of selected pairs. When necessary, data were transformed to obtain normality and homogeneity of variances. In all cases, a significance level of $\alpha=0.05$ was used. All tests were performed using GraphPad Prism version 5.04 (San Diego, CA, USA).

\section{Results}

Effects of cortisol and DOC on $\mathrm{Na}^{+}, \mathrm{K}^{+}$-ATPase $\alpha 1$ (NKA 1 1) transcript level

In tilapia, no effect of hormones or their antagonists were observed on NKA 1 in gills from FW-acclimated fish, whereas cortisol and DOC both increased this transcript in gills from SW-acclimated specimens (Fig. 1A and B). RU486 completely abolished the effect of cortisol. Spironolactone partly abolished the effect of cortisol but was unable to antagonise the effect of DOC on NKA $\alpha 1$ (Fig. 1B).

In striped bass, cortisol induced an increase in the NKA 1 mRNA level but significantly only in gills from SWacclimated fish (Fig. 2A and B). RU486 and spironolactone both abolished the cortisol effect (Fig. 2B). DOC had an inhibitory effect on NKA 1 mRNA in gills from FW- and 


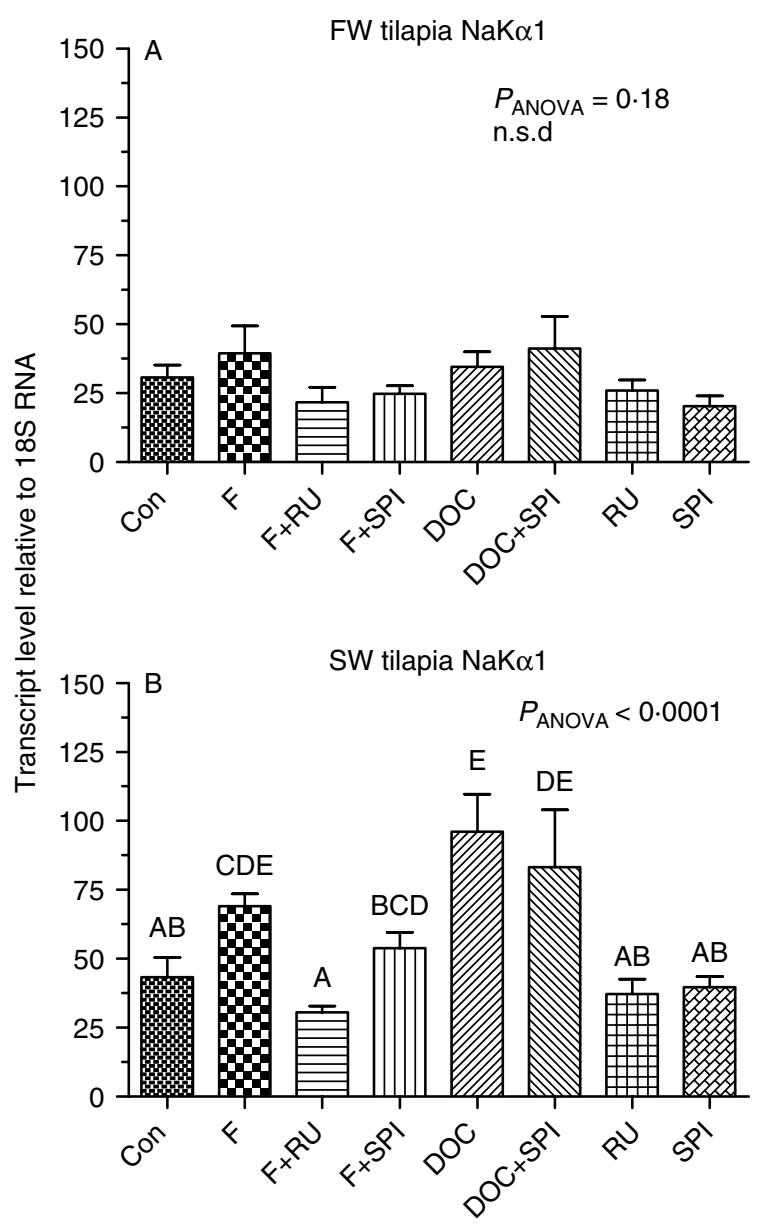

Figure 1 In vitro effect of $10 \mu \mathrm{g} / \mathrm{ml}$ cortisol (F) and 11-deoxycorticosterone (DOC) on $\mathrm{Na}^{+}, \mathrm{K}^{+}$-ATPase $\alpha 1$ (NaK $\alpha 1$ ) mRNA expression in FW- (A) and SW- (B) acclimated tilapia gill. The specificity of the corticosteroid signalling pathway was investigated using specific GR and MR antagonists (RU486 (RU) and spironolactone (Spi) respectively). Target gene mRNA levels are normalised to $18 \mathrm{~S}$ rRNA levels and expressed as arbitrary units (mean \pm S.E.M., $n=6$ ). One-way ANOVA $P$ value is indicated on the figure. Letters above the bars indicate statistical groupings (Student-Newman-Keuls test). When letters are shared among groups, they are not statistically different $(P<0 \cdot 05)$. N.s.d: no significant difference.

SW-acclimated fish, but the effect was not antagonised by spironolactone (Fig. 2A).

\section{Effect of cortisol and DOC on NKCC transcript levels}

Cortisol treatment increased NKCC1a levels in gills from both FW-and SW-tilapia (Fig. 3A and B), and RU486 and spironolactone both abolished the effect. DOC stimulated NKCC1a levels in gills from SW-acclimated tilapia, and spironolactone reduced the effect of DOC (Fig. 3B). Cortisol had no effect on NKCC1b in both FW-and SW-acclimated tilapia (Fig. 4A and B), whereas DOC significantly increased the NKCC1b levels in SW fish (Fig. 4B). This increase was completely abolished by spironolactone.

In striped bass, cortisol increased NKCC levels in gills from SW-acclimated fish but not from FW-acclimated fish (Fig. 5A and B). This effect was completely abolished by RU486 and to a smaller degree by spironolactone (Fig. 5B). DOC decreased the NKCC level in gills from FW-acclimated fish but had no effect in gills from SW-acclimated fish (Fig. 5A). The effect on gills from FW-acclimated fish was partly antagonised by spironolactone.

\section{Sensitivity to hormones in relation to salinity}

In total, three graded doses of cortisol and DOC were tested on tilapia and striped bass gill blocks from both FW and SW fish to compare the sensitivity to the hormones with respect to acclimation salinity. Cortisol doses $<10 \mu \mathrm{g} / \mathrm{ml}(0 \cdot 1$ and $1 \cdot 0 \mu \mathrm{g} / \mathrm{ml}$ ) generally had no effect on any transcript level

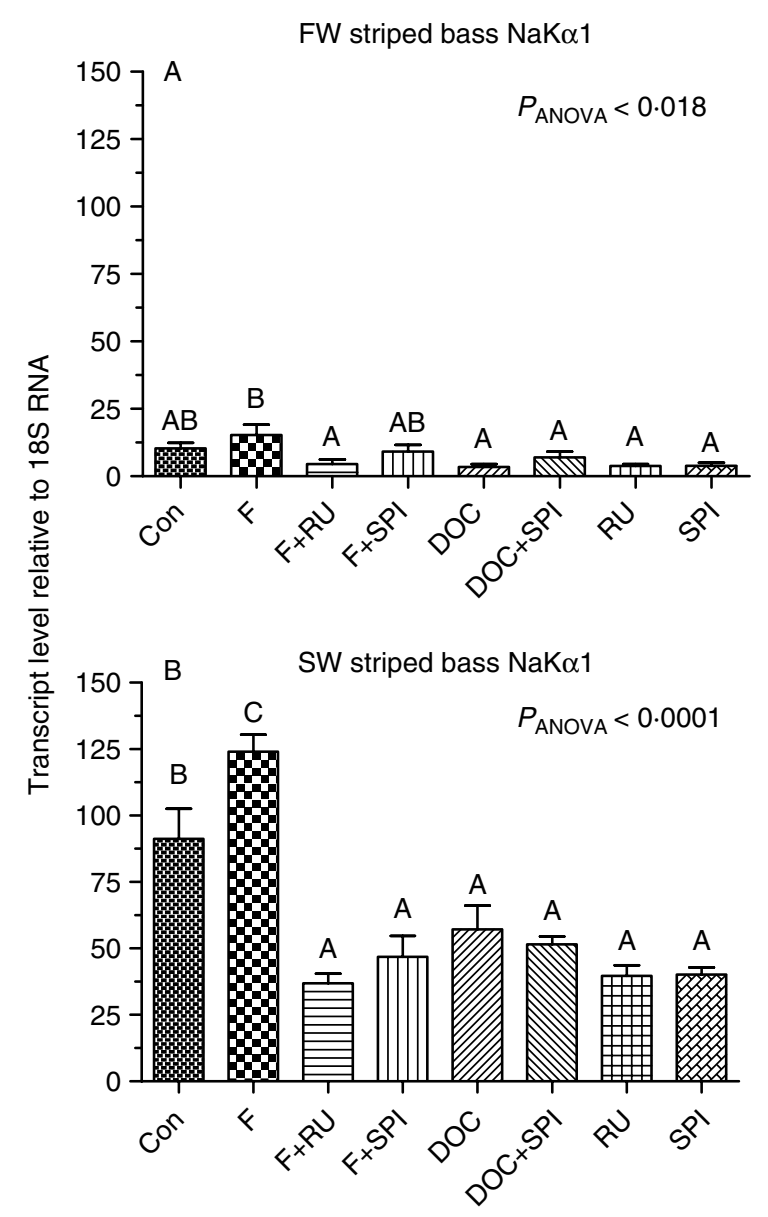

Figure 2 In vitro effect of cortisol and DOC on $\mathrm{Na}^{+}, \mathrm{K}^{+}$-ATPase $\alpha 1$ $(\mathrm{NaK} \alpha 1) \mathrm{mRNA}$ expression in FW- (A) and SW- (B) acclimated striped bass gill. One-way ANOVA $P$ value is indicated on the figure. Letters above the bars indicate statistical groupings (Student-Newman-Keuls test). When letters are shared among groups, they are not statistically different $(P<0 \cdot 05)$. For further details see legend to Fig. 1 . 


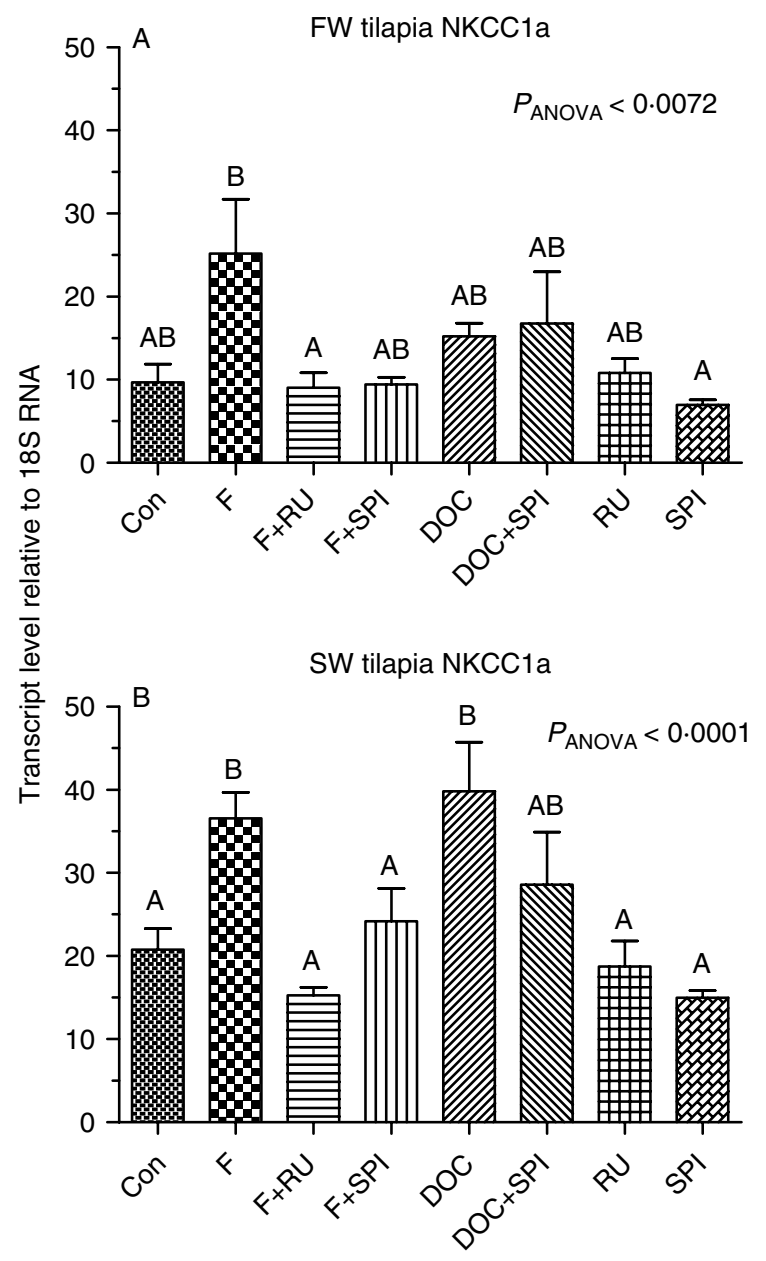

Figure 3 In vitro effect of cortisol and DOC on NKCC1a mRNA expression in FW- (A) and SW- (B) acclimated tilapia gill. One-way ANOVA $P$ value is indicated on the figure. Letters above the bars indicate statistical groupings (Student-Newman-Keuls test). When letters are shared among groups, they are not statistically different $(P<0 \cdot 05)$. For further details see legend to Fig. 1 .

irrespective of salinity and species (data not shown). In FW striped bass gills, DOC decreased $\mathrm{Na}^{+}, \mathrm{K}^{+}$-ATPase $\alpha 1$ subunit and NKCC transcript levels irrespective of dose $(0 \cdot 1,1 \cdot 0$ and $10 \mu \mathrm{g} / \mathrm{ml} ;$ Fig. 6), whereas in SW only the high dose $(10 \mu \mathrm{g} / \mathrm{ml})$ had an effect (not shown). There was no effect of DOC doses below $10 \mu \mathrm{g} / \mathrm{ml}$ in FW- and SW-acclimated tilapia (not shown). A summary of the qualitative effects of cortisol and DOC in the two species is shown in Fig. 8.

Rapid effects of cortisol and DOC on ERK phosphorylation in tilapia and striped bass gills

Incubation of tilapia gill blocks with either cortisol or DOC for $30 \mathrm{~min}$ significantly increased the phosphorylation state of ERK1 and ERK2, thus activating the MAPK phosphorylation cascade (Fig. 7). In FW-acclimated tilapia, ERK2 was activated by cortisol and DOC, whereas ERK1 was activated in gills from SW-acclimated fish by both hormones. In striped bass, cortisol and DOC activated ERK1 in gills from FW-acclimated fish, while they had no effect in gills from SW-acclimated fish.

\section{Discussion}

In fish, cortisol is well known for its ion-regulatory effects. The duality of effects on ion retention in FW and ion secretion in SW is in part a consequence of interaction with elements of the GH/PRL-IGF-1 axis (Tipsmark \& Madsen 2009), but the underlying molecular mechanisms and the signalling pathways remain largely unknown. We investigated the effect

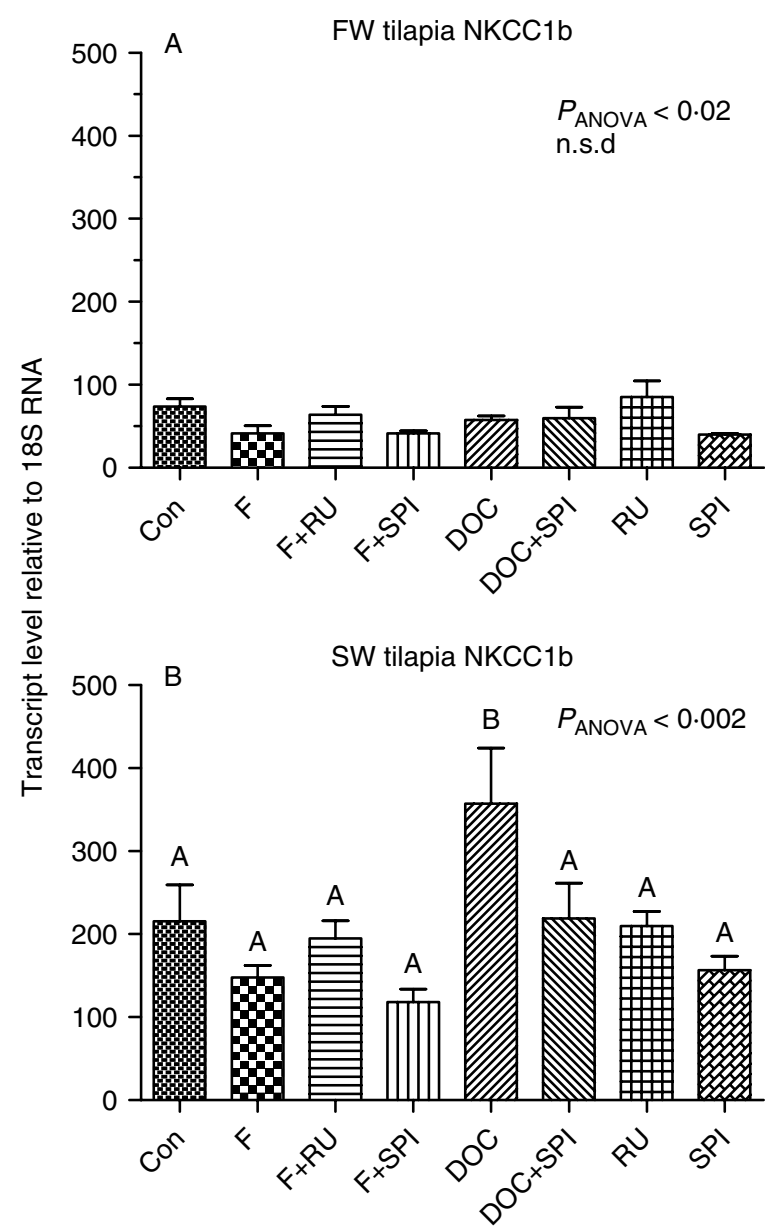

Figure 4 In vitro effect of cortisol and DOC on NKCC1b mRNA expression in FW- (A) and SW- (B) acclimated tilapia gill. One-way ANOVA $P$ value is indicated on the figure. Letters above the bars indicate statistical groupings (Student-Newman-Keuls test). When letters are shared among groups, they are not statistically different $(P<0 \cdot 05)$. N.s.d: no significant difference. For further details see legend to Fig. 1. 


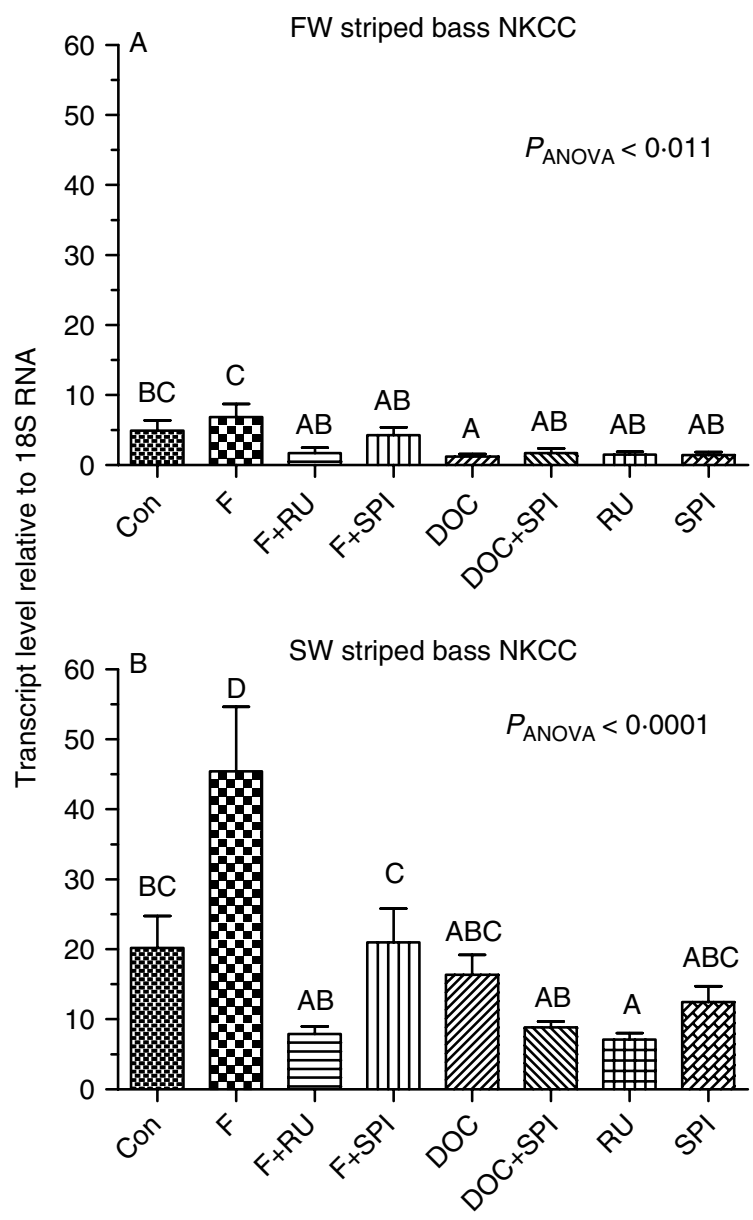

Figure 5 In vitro effect of cortisol and DOC on NKCC mRNA expression in FW- (A) and SW- (B) acclimated striped bass gill. Oneway ANOVA $P$ value is indicated on the figure. Letters above the bars indicate statistical groupings (Student-Newman-Keuls test). When letters are shared among groups, they are not statistically different $(P<0 \cdot 05)$. For further details see legend to Fig. 1 .

of cortisol and the recently discovered mineralocorticoid DOC in isolated gill tissue of FW- versus SW-acclimated fish to attain a better understanding of their function in salinity acclimation and the potential receptor-mediated process through which they act. We report that DOC has an ionregulatory potential in the gill of euryhaline fish and demonstrate that cortisol's actions and signalling pathways in gill function may be species specific and related to the strategy for coping with fluctuations in salinity.

\section{Doses of hormones}

Only the highest dose of cortisol $(10 \mu \mathrm{g} / \mathrm{ml})$ had an effect on target gene mRNA levels in tilapia and striped bass gill in this study. This dose may be considered supraphysiological even though peak plasma levels during acute stress have been reported up to $0 \cdot 3-0 \cdot 4$ and $0 \cdot 8-2 \cdot 0 \mu \mathrm{g} / \mathrm{ml}$ in tilapia and striped bass respectively (Mazik et al. 1991, Balm et al. 1994, Noga et al. 1994, Barcellos et al. 1999, Davis \& McEntire 2009, Breves et al. 2010). For yet unknown reasons, relatively high levels of corticosteroids $(1-10 \mu \mathrm{g} / \mathrm{ml})$ are generally needed in order to evoke the effects on gill explants in vitro (e.g. McCormick \& Bern 1989, McCormick et al. 1991, Kiilerich et al. 2010). The actual tissue and cellular level of cortisol in our study is unknown but may be much lower than $10 \mu \mathrm{g} / \mathrm{ml}$ due to diffusion limitations caused by mucus secretion by the gills during incubation. The cortisol dose needed for a response may vary according to species and experimental conditions, since lower levels of cortisol can manipulate enzyme transcription and activity in other species such as rainbow trout $\left(\mathrm{Na}^{+}, \mathrm{K}^{+}\right.$-ATPase: Shrimpton \& McCormick 1999, lactate dehydrogenase activity: Mazon et al. 2004) and sea bream $\left(\mathrm{Na}^{+}, \mathrm{K}^{+}\right.$-ATPase $\alpha$ subunit mRNA, but not enzyme activity: Deane \& Woo 2005). In three-dimensional simpler models such as opercular membrane or cultured gill epithelia, cortisol also exerts effects at lower doses $(0 \cdot 1-1 \mu \mathrm{g} / \mathrm{ml}$; e.g. McCormick 1990, Chasiotis et al. 2010).

With regard to DOC, information on plasma levels is indeed scarce. One study reported DOC plasma levels in tilapia around $0 \cdot 0005-0.0006 \mu \mathrm{g} / \mathrm{ml}$, with an increase up to $0.022 \mu \mathrm{g} / \mathrm{ml}$ during spawning (Katz \& Eckstein 1974). No data are available in striped bass. In order to compare the potency of DOC with that of cortisol, equal concentration of the two hormones was applied routinely. However, in a single experiment with FW striped bass, 10- to 100-fold lower doses of DOC induced the same qualitative effects as $10 \mu \mathrm{g} / \mathrm{ml}$ (see later).

$\mathrm{Na}^{+}, \mathrm{K}^{+}$-ATPase and NKCC isoforms and $m R N A$ levels in gills from $F W$ - and $S W$-acclimated fish

The transcript level of two response genes was investigated: the $\mathrm{Na}^{+}, \mathrm{K}^{+}$-ATPase $\alpha 1$ subunit, being responsible for maintaining the electrochemical potential for ion transport

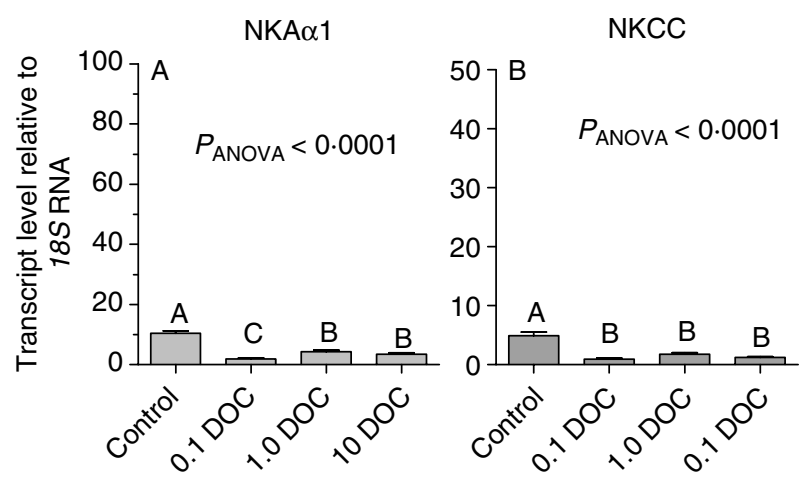

Figure 6 The effect of graded doses of DOC $(10,1$ and $0 \cdot 1 \mu \mathrm{g} / \mathrm{ml})$ on $\mathrm{Na}^{+}, \mathrm{K}^{+}$-ATPase $\alpha 1$ ( NaK $\alpha 1$; in $\left.\mathrm{A}\right)$ and $\mathrm{NKCC}(\mathrm{B})$ transcript levels in FW-acclimated striped bass gills. One-way ANOVA $P$ value is indicated on the figure. Letters above the bars indicate statistical groupings (Student-Newman-Keuls test). When letters are shared among groups, they are not statistically different $(P<0 \cdot 05)$. 

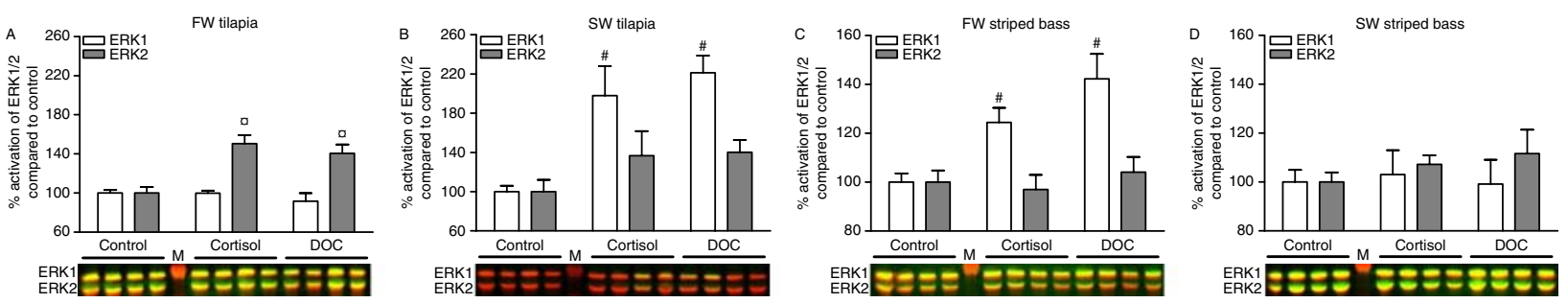

Figure 7 In vitro activation of ERK1 and ERK2 by cortisol and DOC in tilapia and striped bass gill is dependent on the acclimation salinity. Gill blocks from FW- (A and C) and SW- (B and D) acclimated fish were incubated with cortisol or DOC for 30 min at room temperature before homogenisation, gel electrophoresis and western blotting. The amount of activated (dual phosphorylated) ERK1/2 was calculated relative to the total amount of total ERK1/2 in each sample. Control wells are set to $100 \%$, and the relative activation is given in percentage (values are mean \pm S.E.M., $n=4)$. \# and o indicate significant difference from ERK1 and ERK2 control respectively. The western blot section below the graph illustrates the overlay of non-phosphorylated (red) and dual phosphorylated (green) ERK1 (upper band) and ERK2 (lower band). The protein marker band $(\mathrm{M})$ is indicated at $50 \mathrm{kDa}$. Full colour version of this figure available via http://dx.doi.org/10.1530/JOE-10-0326.

in both hypo- and hyperosmotic environment, and the NKCC, which facilitates ion excretion under hyperosmotic conditions (see Marshall (2002)). Until now, only one $\mathrm{Na}^{+}, \mathrm{K}^{+}$-ATPase $\alpha 1$ isoform has been reported in the diploid tilapia (Hwang et al. 1998) and striped bass (Madsen et al. 2007) compared with the three $\alpha 1$ isoforms identified in the tetraploid salmon gill, $\alpha 1 \mathrm{a}, \alpha 1 \mathrm{~b}$ and $\alpha 1 \mathrm{c}$ (Richards et al. 2003). Several studies in salmonids have demonstrated reciprocal changes of $\alpha 1 \mathrm{a}$ and $\alpha 1 \mathrm{~b}$ isoforms when salinity changes, with $\mathrm{Na}^{+}, \mathrm{K}^{+}$-ATPase $\alpha 1 \mathrm{a}$ as the predominant FW isoform and $\alpha 1 b$ as the predominant SW isoform
(Richards et al. 2003, Madsen et al. 2009). The tilapia and striped bass sequences analysed in this study share highest homology with the salmonid $\alpha 1 \mathrm{~b}$ (SW type) isoform (BLAST, $\alpha 1 \mathrm{~b}>\alpha 1 \mathrm{c}>\alpha 1 \mathrm{a})$. Indeed, we found that SW striped bass had higher levels of $\mathrm{Na}^{+}, \mathrm{K}^{+}$-ATPase $\alpha 1$ mRNA than FW fish (Fig. 2A compared with $2 \mathrm{~B}, P<0 \cdot 01$ ), whereas this was not significant in tilapia (Fig. 1A and B). An increase in $\mathrm{Na}^{+}, \mathrm{K}^{+}{ }_{-}$ ATPase $\alpha 1$ subunit mRNA may subsequently lead to a change in $\mathrm{Na}^{+}, \mathrm{K}^{+}$-ATPase $\alpha$ subunit protein and thus enzymatic activity as described previously for FW-SW and FW-brackish water-transferred tilapia (Lin et al. 2004, Wang et al. 2009).

\begin{tabular}{|c|c|c|c|c|c|c|c|c|c|c|}
\hline \multicolumn{5}{|c|}{ Tilapia gill } & & \multicolumn{5}{|c|}{ Striped bass gill } \\
\hline \multicolumn{2}{|l|}{ FW } & \multicolumn{3}{|c|}{ SW } & \multicolumn{3}{|c|}{ FW } & & \multicolumn{2}{|c|}{ SW } \\
\hline Chloride $\mathrm{c}$ & & \multicolumn{3}{|c|}{ Shloride cell } & \multicolumn{3}{|c|}{ Chloride cell } & \multicolumn{3}{|c|}{ Chloride cell } \\
\hline \multicolumn{2}{|c|}{ aNKA NKCC1a NKCC1b } & \multicolumn{3}{|c|}{$\alpha \mathrm{NKA} N K C C 1 \mathrm{a} N K C \mathrm{~N} 1 \mathrm{~b}$} & \multicolumn{3}{|c|}{$\alpha$ NKA NKCC } & \multicolumn{3}{|c|}{$\alpha$ NKA NKCC } \\
\hline Cortisol & $\begin{array}{l}\text { DOC } \\
\text { no effect) }\end{array}$ & Cortis & & DOC & & rtisol & DOC & & ortisol & DÒC \\
\hline Species & & & Tila & & & & & Stripe & bass & \\
\hline Salinity & & FW & & & SW & & $\mathrm{FV}$ & & & W \\
\hline $\begin{array}{c}\text { Target } \\
\text { Treatment }\end{array}$ & NKA $\alpha 1$ & NKCC1a & NKCC1b & NKA $\alpha 1$ & NKCC1a & NKCC1b & NKA $\alpha 1$ & NKCC1a & NKA $\alpha 1$ & NKCC1a \\
\hline $\mathrm{F}$ & 0 & + & 0 & + & + & 0 & $(+)$ & $(+)$ & + & + \\
\hline $\mathrm{F}+\mathrm{RU}$ & 0 & 0 & 0 & 0 & 0 & 0 & 0 & 0 & 0 & 0 \\
\hline $\mathrm{F}+\mathrm{SPI}$ & 0 & 0 & 0 & $(-)$ & 0 & 0 & 0 & 0 & 0 & 0 \\
\hline DOC & 0 & 0 & 0 & + & + & + & - & - & - & 0 \\
\hline $\mathrm{DOC}+\mathrm{SPI}$ & 0 & 0 & 0 & + & 0 & 0 & (0) & 0 & - & 0 \\
\hline
\end{tabular}

Figure 8 Schematic summary of the main findings of the study. The diagram illustrates target gene transcripts within gill chloride cells of FW- and SW-acclimated tilapia and striped bass. Observed effects of cortisol and DOC are shown by a line with arrowhead (stimulation) or bar (inhibition) near the target. $\alpha \mathrm{NKA}, \alpha 1$-subunit of the $\mathrm{Na}^{+}, \mathrm{K}^{+}$-ATPase; NKCC1(a/b), isoforms of the $\mathrm{Na}^{+}, \mathrm{K}^{+}, 2 \mathrm{Cl}^{-}$cotransporter. Dashed line indicates that the effect is not verified by antagonist treatment. In the table given, ' 0 ' denotes no effect; ' + ' denotes stimulatory effect; ' -' denotes inhibitory effect; () denotes tendency but not significant; light shading indicates 'blocking' with antagonist; dark shading indicates 'no blocking' with antagonist. 
Our comparison was, however, based on control gill samples incubated in minimal medium for $24 \mathrm{~h}$, during which time there may have been a degradation of mRNA due to natural turnover in the tissue (Madsen et al. 2007).

Two NKCC1 isoforms have been identified in tilapia, NKCC1a and NKCC1b (Hiroi et al. 2008). The NKCC1a was termed a secretory type based on its higher level in tilapia gill after SW transfer (Hiroi et al. 2008, Inokuchi et al. 2008). Only one NKCC1 (partial) sequence has been described in striped bass (Tipsmark et al. 2004), and a BLAST search suggests this to be the secretory NKCC1a isoform. Accordingly, the level of NKCC1a in striped bass and tilapia gills was higher in $\mathrm{SW}$ than in FW (Figs 3 and $5, P<0 \cdot 01$ for both transcripts). This is consistent with other fish species (reviewed by Scott et al. (2004), Tipsmark et al. (2004), Evans et al. (2005), Lorin-Nebel et al. (2006), Nilsen et al. (2007) and Tang \& Lee (2007)) and agrees with the ion-secretory roles assigned for this ion transporter (Evans et al. 2005).

We also found that the NKCC1b tilapia isoform was elevated in gills from SW versus FW-acclimated tilapia (Fig. 4, $P<0 \cdot 05)$. Investigations of the role of NKCC1b in the gill are scarce, and we can only note that the higher level of NKCC1b in SW-acclimated tilapia compared with FWacclimated tilapia in this study is inconsistent with the studies of Hiroi et al. (2008), where NKCC1b levels were the same or lower in SW compared with FW.

\section{$\mathrm{Na}^{+}, \mathrm{K}^{+}$-ATPase and cortisol}

A stimulatory effect of cortisol on gill $\mathrm{Na}^{+}, \mathrm{K}^{+}$-ATPase $\alpha$ subunit and isoform transcripts, protein and activity levels in vivo and in vitro is well established in salmonids (see Mommsen et al. (1999), McCormick et al. (2008) and Tipsmark \& Madsen (2009)). In both tilapia and striped bass, cortisol also stimulated $\mathrm{Na}^{+}, \mathrm{K}^{+}$-ATPase $\alpha$ subunit transcript levels significantly but only in gills from SW-acclimated fish and not in gills from FW-acclimated fish. For tilapia, this is at variance with Dang et al. (2000) who showed that cortisol stimulated $\mathrm{Na}^{+}, \mathrm{K}^{+}$-ATPase protein density in chloride cells in FW-acclimated tilapia. On the other hand, Dangé (1986) showed that cortisol had a much stronger effect on gill $\mathrm{Na}^{+}, \mathrm{K}^{+}$-ATPase activity when injected into SW-compared with FW-acclimated tilapia (Dangé 1986). In striped bass, only one previous study has analysed the effect of cortisol on gill $\mathrm{Na}^{+}, \mathrm{K}^{+}$-ATPase. Madsen et al. (2007) found either no effect of cortisol on $\mathrm{Na}^{+}, \mathrm{K}^{+}$-ATPase activity or $\boldsymbol{\alpha}$-subunit mRNA when injected into $\mathrm{FW}$-acclimated fish in vivo or a very weak stimulatory effect when applied to gill tissue of FW-acclimated fish directly in vitro for $24 \mathrm{~h}$. These authors did not, however, investigate SW-acclimated fish. Thus, the present experiments indicate that tilapia and striped bass gills respond similarly to cortisol in vitro - though only when acclimated to SW. The apparent salinity dependent effect is likely explained by differences in gill corticosteroid receptors (CR) and thus increased sensitivity after SW transfer (Dean et al. 2003).
The similar pattern of response to cortisol in the two Perciforms does not support our initial hypothesis that cortisol would be more important in tilapia than in striped bass during acclimation to increased salinity. However, when we analyse the cortisol signalling pathways involved in the response, the two species seem to differ. In SW-acclimated tilapia, the fully antagonistic effect of RU486, but not spironolactone, suggests that a higher proportion of cortisol signalling may occur through a GR type rather than a MR type receptor (Fig. 1B). In SW striped bass, both RU486 and spironolactone completely abolished cortisol's effect on $\mathrm{Na}^{+}, \mathrm{K}^{+}$-ATPase $\alpha 1$ (Fig. 2B), suggesting a role for GR and MR alike. RU486 is considered to be an efficient and specific antagonist for the GR and has been used several times with success in fish (Bury et al. 2003, Scott et al. 2005, Kiilerich et al. 2007, Shaw et al. 2007). On the other hand, the efficiency of spironolactone as an antagonist in fish has been questioned by Sturm et al. (2005). While an agonistic effect of spironolactone was reported in mammalian COS cells using rainbow trout MR (Sturm et al. 2005), spironolactone has been used both in vivo and in in vitro organ culture without undesired agonistic effects in fish (Sloman et al. 2001, Scott et al. 2005, Kiilerich et al. 2007). Accordingly, there are no agonistic effects nor any consistent overall pharmacological effect of spironolactone observed in this study.

Collectively, gills from SW-acclimated tilapia and striped bass are more responsive to cortisol than gills from FW-acclimated fish in respect to regulation of $\mathrm{Na}^{+}, \mathrm{K}^{+}{ }_{-}$ ATPase $\alpha 1 \mathrm{mRNA}$ levels. This differs from the situation in Atlantic salmon, where both $\alpha 1 \mathrm{a}$ and $-1 \mathrm{~b}$ subunits of the $\mathrm{Na}^{+}, \mathrm{K}^{+}$-ATPase are stimulated by cortisol in gills from FW- as well as SW-acclimated fish (Kiilerich et al. 2007). Whether this difference between euryhaline salmoniform and Perciform teleosts reflects their evolutionary origin or their adopted life cycle is uncertain. Salmonids developmentally acquire salinity tolerance in a narrow time window during smoltification, whereas tilapia and striped bass may acclimate at all life stages. Further investigations are required to dissect the underlying mechanisms for the altered cortisol responsiveness among species with different acclimation strategies.

\section{NKCC and cortisol}

In striped bass, cortisol stimulated gill NKCC transcript levels only in SW-acclimated fish (Fig. 5). In FW, there was no effect of cortisol; however, RU486 significantly decreased the transcript level both alone and in combination with cortisol, suggesting that endogenous cortisol may have stimulated the GR in the cultured control gills. This resembles the regulation patterns observed with a similar experiment in Atlantic salmon (Kiilerich et al. 2007) and is in good agreement with the up-regulation of NKCC mRNA and protein levels after FW to SW transfer of striped bass (Tipsmark et al. 2004) and the SW adaptive role for cortisol and NKCC. 
Tilapia differs from striped bass as cortisol caused an up-regulation of NKCC1a transcript levels in both FW and SW, which must be seen as a strong SW adaptive effect of cortisol in this species. Cortisol did not affect expression of the alternative isoform NKCC1b in tilapia gill, which supports different functions of the two isoforms as suggested by Hiroi et al. (2008). RU486 and spironolactone efficiently blocked the stimulatory effect of cortisol in both species suggesting that both GR and $\mathrm{MR}$ are involved in the signalling mechanism (Figs 3 and 5B). Together with the cortisolmediated up-regulation of the secretory NKCC protein levels in the gill of salmonids (Pelis \& McCormick 2001, Tipsmark et al. 2002), this suggests a general ability of cortisol to up-regulate the secretory NKCC isoform in the gill in these species, thereby promoting monovalent ion secretion.

\section{Effect of DOC}

Only very few studies have investigated the effects of DOC on osmoregulatory targets in fish. In vivo treatment with DOC does not affect gill $\mathrm{Na}^{+}, \mathrm{K}^{+}$-ATPase $\alpha$ subunit mRNA level or activity in Atlantic salmon, and blocking of the MR with spironolactone had also no effect (McCormick et al. 2008). However, Kiilerich et al. (2010) reported an ability of DOC to up-regulate FW Atlantic salmon gill $\mathrm{Na}^{+}, \mathrm{K}^{+}$-ATPase $\alpha 1 \mathrm{a}$ and $\alpha 1 \mathrm{~b}$ mRNA in vitro, suggesting a potential osmoregulatory function of DOC. In this study, DOC conferred a significant up-regulation of $\mathrm{Na}^{+}, \mathrm{K}^{+}$-ATPase $\alpha 1$, NKCC1a and NKCC1b transcripts levels in SW- but not FWacclimated tilapia gill. In striped bass, DOC down-regulated $\mathrm{Na}^{+}, \mathrm{K}^{+}$-ATPase $\alpha 1$ in gills from FW- and SW-acclimated fish, and NKCC in gills from FW-acclimated fish only. The inhibitory effect in gills from FW-acclimated fish was verified at doses ranging from $0 \cdot 1$ to $1 \mu \mathrm{g} / \mathrm{ml}$, whereas these doses had no effects on any other transcript at both salinities. Interestingly, while DOC and cortisol had similar effect on $\mathrm{Na}^{+}, \mathrm{K}^{+}$-ATPase $\alpha 1$ and NKCC1a in SW tilapia, the two hormones had disparate effects on other targets (Fig. 7). For instance, in tilapia, DOC had no effect on NKCC1a in gills from $\mathrm{FW}$-acclimated fish, while cortisol conferred an up-regulation. Further, DOC treatment induced an upregulation of NKCC1b in gills from SW-acclimated fish, while cortisol had no effect. In striped bass, DOC induced down-regulation of $\mathrm{Na}^{+}, \mathrm{K}^{+}$-ATPase $\alpha 1$ and NKCC in gills from FW-acclimated fish, while cortisol had a weak stimulatory effect. Finally, DOC had no effect on NKCC in gills from SW-acclimated fish, where cortisol induced an up-regulation. In some (SW tilapia NKCC1a, NKCC1b and FW striped bass NKA, NKCC), but not in all cases (SW tilapia NKA, SW striped bass NKA), the effect of DOC was effectively blocked by the mineralocorticoid antagonist spironolactone. Yet, since DOC is a specific agonist for MR only (Sturm et al. 2005), an inadequate concentration of spironolactone most likely explains the lack of inhibition of the DOC-MR signal.

\section{Rapid effects of corticosteroids}

In the classical view of steroid hormone action steroids mainly work through intracellular receptors to regulate transcriptional rates of target genes and the subsequent regulation of proteins and target cell activity. This signalling pathway is generally slow, typically with latency periods of hours to days. However, corticosteroids may also rapidly regulate target cell activity through non-genomic mechanisms of actions (Borski 2000). Corticosteroids may also exert rapid and/or non-genomic effects on ion transport (see Sakamoto et al. (2001) and McCormick \& Bradshaw (2006)) as has been demonstrated for aldosterone on ion regulation in tetrapods (see Harvey et al. (2002)). In fish, rapid effects of glucocorticoids have been reported with regard to inhibition of pituitary prolactin release in tilapia (Borski et al. 2001, 2002, Hyde et al. 2004), lipogenic enzyme activity in tilapia liver cells (Sunny et al. 2002) and on $\mathrm{Na}^{+}, \mathrm{K}^{+}$-ATPase activity in the eel and tilapia gill (Marsigliante et al. 2000, Sunny \& Oommen 2001). We demonstrate in this study that both cortisol and DOC may rapidly affect (within $30 \mathrm{~min}$ ) the MAPK signalling cascade via an increase in the phosphorylation state of ERK1 and ERK2. We speculate that this may further affect ion channel and ion transport activity downstream as observed for MDCK cells (see Harvey et al. (2002)). Whether this effect is independent of gene transcription and is mediated through classical cytosolic or putative membrane-bound corticosteroid receptors remains to be determined. Interestingly, the observed effects were dependent on the acclimation salinity and fish species, which might reflect variation in corticosteroid receptor profiles in target cells.

\section{Conclusion}

In relation to our initial hypothesis, the corticosteroid sensitivity and response pattern on ion-transporting proteins in the gill indeed seems to differ in tilapia and striped bass (summarised in Fig. 7). Thus, the innate differences in salinity acclimation strategies among the two species are reflected by differences in corticosteroid regulation of ion transporter genes at the level of the gill. Especially when judged by the effect of DOC, which has an overall stimulatory effect on the three targets in the gill from SW-acclimated tilapia, an overall inhibitory effect on the two investigated targets in the gill from FW striped bass was observed. Based on our current understanding of the combined ion-regulatory role of $\mathrm{Na}^{+}, \mathrm{K}^{+}$-ATPase and NKCC in the gill, the effect of DOC seems in favour of hypo-osmoregulation in tilapia and hyperosmoregulation in the striped bass. With regard to cortisol's effects, there is evidence of both glucocorticoid and MRs being involved, the overall action of cortisol being in favour of hypo-osmoregulation in both species. DOC has distinct as well as overlapping actions on ion transporter 
gene regulation, suggesting that the two corticosteroids may coordinate their actions, presumably through distinct GR and MR receptors to accurately regulate target gene transcription.

\section{Declaration of interest}

The authors declare that there is no conflict of interest that could be perceived as prejudicing the impartiality of the research reported.

\section{Funding}

P K was supported by a grant from the School of Aquatic Sciences (SOAS, Denmark). C K T was supported by a grant from the Danish Natural Science Foundation (21-04-0035). R J B was supported by grants from the US NSF (IBN-0215205), the US Agency for International Development (Aquaculture and Fisheries Collaborative Research Support Program, \#EPP-A-00-06-00012-00) and the US Department of Agriculture (200934368-19776). S S M was supported by a grant from the Danish Natural Research Council (09-070689).

\section{References}

Assem H \& Hanke W 1981 Cortisol and osmotic adjustment of the euryhaline teleost, Sarotherodon mossambicus. General and Comparative Endocrinology $\mathbf{4 3}$ 370-380. (doi:10.1016/0016-6480(81)90297-5)

Balm PHM, Pepels P, Helfrich S, Hovens MLM \& Wendelaar Bonga SE 1994 Adrenocorticotropic hormone in relation to interrenal function during stress in tilapia (Oreochromis mossambicus). General and Comparative Endocrinology 96 347-360. (doi:10.1006/gcen.1994.1190)

Barcellos LJG, Nicolaiewsky S, de Souzan SMG \& Lulhier F 1999 Plasmatic levels of cortisol in the response to acute stress in Nile tilapia, Oreochromis niloticus (L.), previously exposed to chronic stress. Aquaculture Research 30 437-444. (doi:10.1046/j.1365-2109.1999.00348.x)

Borski RJ 2000 Nongenomic, membrane actions of glucocorticoids in vertebrates. Trends in Endocrinology and Metabolism 11 427-436. (doi:10.1016/S1043-2760(00)00325-8)

Borski RJ, Hyde GN, Fruchtman S \& Tsai WS 2001 Cortisol suppresses prolactin release through a nongenomic mechanism involving interactions with the plasma membrane. Comparative Biochemistry and Physiology. Part B, Biochemistry \& Molecular Biology 129 533-541. (doi:10.1016/S10964959(01)00358-X)

Borski RJ, Hyde GN \& Fruchtman S 2002 Signal transduction mechanisms mediating rapid, nongenomic effects of cortisol on prolactin release. Steroids 67 539-548. (doi:10.1016/S0039-128X(01)00197-0)

Breves JP, Hirano T \& Grau EG 2010 Ionoregulatory and endocrine responses to disturbed salt and water balance in Mozambique tilapia exposed to confinement and handling stress. Comparative Biochemistry and Physiology. Part A, Molecular \& Integrative Physiology 155 294-300. (doi:10.1016/j.cbpa. 2009.10.033)

Bury NR, Sturm A, Le Rouzic P, Lethimonier C, Ducouret B, Guiguen Y, Robinson-Rechavi M, Laudet V, Rafestin-Oblin ME \& Prunet P 2003 Evidence for two distinct functional glucocorticoid receptors in teleost fish. Journal of Molecular Endocrinology 31 141-156. (doi:10.1677/jme.0.0310141)

Chasiotis H, Wood CM \& Kelly SP 2010 Cortisol reduces paracellular permeability and increases occludin abundance in cultured trout gill epithelia. Molecular and Cellular Endocrinology 323 232-238. (doi:10.1016/ j.mce.2010.02.030)

Dang Z, Balm PH, Flik G, Wendelaar Bonga SE \& Lock RA 2000 Cortisol increases $\mathrm{Na}(+) / \mathrm{K}(+)$-ATPase density in plasma membranes of gill chloride cells in the freshwater tilapia Oreochromis mossambicus. Journal of Experimental Biology 203 2349-2355.
Dangé AD 1986 Branchial NaKATPase activity in fresh-water or saltwater acclimated tilapia Oreochromis (Sarotherodon) mossambicus - effects of cortisol and thyroxine. General and Comparative Endocrinology 62 341-343. (doi:10. 1016/0016-6480(86)90125-5)

Davis KB \& McEntire M 2009 Comparison of the cortisol and glucose stress response to acute confinement among white bass, Morone chrysops, striped bass, Morone saxatilis, and sunshine bass, Morone chrysops X Morone saxatilis. Journal of the World Aquaculture Society 40 567-572. (doi:10.1111/j.17497345.2009.00275.x)

Dean DB, Whitlow ZW \& Borski RJ 2003 Glucocorticoid receptor upregulation during seawater adaptation in a euryhaline teleost, the tilapia (Oreochromis mossambicus). General and Comparative Endocrinology 132 112-118. (doi:10.1016/S0016-6480(03)00053-4)

Deane EE \& Woo NYS 2005 Cloning and characterization of sea bream $\mathrm{Na}^{+}-\mathrm{K}^{+}$-ATPase $\alpha$ and $\beta$ subunit genes: In vitro effects of hormones on transcriptional and translational expression. Biochemical and Biophysical Research Communications 331 1229-1238. (doi:10.1016/j.bbrc.2005.04.038)

Evans DH, Piermarini PM \& Choe KP 2005 The multifunctional fish gill: dominant site of gas exchange, osmoregulation, acid-base regulation, and excretion of nitrogenous waste. Physiological Reviews 85 97-177. (doi:10. 1152/physrev.00050.2003)

Haller J, Mikics E \& Makara GB 2008 The effects of non-genomic glucocorticoid mechanisms on bodily functions and the central neural system. A critical evaluation of findings. Frontiers in Neuroendocrinology 29 273-291. (doi:10.1016/j.yfrne.2007.10.004)

Harvey BJ, Alzamora R, Healy V, Renard C \& Doolan CM 2002 Rapid responses to steroid hormones: from frog skin to human colon. A homage to Hans Ussing. Biochimica et Biophysica Acta 1566 116-128 (Review). (doi:10.1016/S0005-2736(02)00589-8)

Hiroi J, Yasumasu S, McCormick SD, Hwang PP \& Kaneko T 2008 Evidence for an apical $\mathrm{Na}-\mathrm{Cl}$ cotransporter involved in ion uptake in a teleost fish. Journal of Experimental Biology 211 2584-2599. (doi:10.1242/jeb.018663)

Hwang PP, Fang MJ, Tsai JC, Huang CJ \& Chen ST 1998 Expression of mRNA and protein of $\mathrm{Na}^{+}-\mathrm{K}^{+}$-ATPase $\alpha$ subunit in gills of tilapia (Oreochromis mossambicus). Fish Physiology and Biochemistry 18 363-373. (doi:10.1023/A:1007711606064)

Hyde GN, Seale AP, Grau EG \& Borski RJ 2004 Cortisol rapidly suppresses intracellular calcium and voltage-gated calcium channel activity in prolactin cells of the tilapia (Oreochromis mossambicus). American Journal of Physiology. Endocrinology and Metabolism 286 E626-E633. (doi:10.1152/ajpendo.00088. 2003)

Inokuchi M, Hiroi J, Watanabe S, Lee KM \& Kaneko T 2008 Gene expression and morphological localization of NHE3, NCC and NKCC1a in branchial mitochondria-rich cells of Mozambique tilapia (Oreochromis mossambicus) acclimated to a wide range of salinities. Comparative Biochemistry and Physiology. Part A, Molecular and Integrative Physiology 151 151-158. (doi:10. 1016/j.cbpa.2008.06.012)

Katz Y \& Eckstein B 1974 Changes in steroid concentration in blood of female Tilapia aurea (teleostei, cichlidae) during initiation of spawning. Endocrinology 95 963-967. (doi:10.1210/endo-95-4-963)

Kiilerich P, Kristiansen K \& Madsen SS 2007 Cortisol regulation of ion transporter mRNA in Atlantic salmon gill and the effect of salinity on the signaling pathway. Journal of Endocrinology 194 417-427. (doi:10.1677/ JOE-07-0185)

Kiilerich P, Pedersen SH, Kristiansen K \& Madsen SS 2010 Corticosteroid regulation of $\mathrm{Na}^{+}, \mathrm{K}^{+}$-ATPase $\alpha 1$-isoform expression in Atlantic salmon gill during smolt development. General and Comparative Endocrinology 170 283-289. (doi:10.1016/j.ygcen.2010.02.014)

Lin CH, Huang CL, Yang CH, Lee TH \& Hwang PP 2004 Time-course changes in the expression of $\mathrm{Na}, \mathrm{K}$-ATPase and the morphometry of mitochondrion-rich cells in gills of euryhaline tilapia (Oreochromis mossambicus) during freshwater acclimation. Journal of Experimental Zoology. Part A, Comparative Experimental Biology 301 85-96. (doi:10.1002/jez.a. 20007)

Lorin-Nebel C, Boulo V, Bodinier C \& Charmantier G 2006 The $\mathrm{Na}^{+} / \mathrm{K}^{+} / 2 \mathrm{Cl}(-)$ cotransporter in the sea bass Dicentrarchus labrax during ontogeny: involvement in osmoregulation. Journal of Experimental Biology 209 4908-4922. (doi:10.1242/jeb.02591) 
Madsen SS, McCormick SD, Young G, Endersen JS, Nishioka RS \& Bern HA 1994 Physiology of seawater acclimation in the striped bass, Morone saxatilis (Walbaum). Fish Physiology and Biochemistry 13 1-11. (doi:10.1007/ BF00004114)

Madsen SS, Jensen LN, Tipsmark CK, Kiilerich P \& Borski RJ 2007 Differential regulation of cystic fibrosis transmembrane conductance regulator and $\mathrm{Na}^{+}, \mathrm{K}^{+}$-ATPase in gills of striped bass, Morone saxatilis: effect of salinity and hormones. Journal of Endocrinology 192 249-260. (doi:10.1677/JOE-06-0016)

Madsen SS, Kiilerich P \& Tipsmark CK 2009 Multiplicity of expression of $\mathrm{Na}^{+}, \mathrm{K}^{+}$-ATPase alpha-subunit isoforms in the gill of Atlantic salmon (Salmo salar): cellular localisation and absolute quantification in response to salinity change. Journal of Experimental Biology 212 78-88. (doi:10.1242/jeb.024612)

Marshall WS $2002 \mathrm{Na}^{+}, \mathrm{Cl}^{-}, \mathrm{Ca}^{2+}$ and $\mathrm{Zn}^{2+}$ transport by fish gills: retrospective review and prospective synthesis. Journal of Experimental Zoology 293 264-283. (doi:10.1002/jez.10127)

Marsigliante S, Muscella A, Vilella S \& Storelli C 2000 Dexamethasone modulates the activity of the eel branchial $\mathrm{Na}^{+} / \mathrm{K}^{+}$-ATPase in both chloride and pavement cells. Life Sciences 66 1663-1673. (doi:10.1016/ S0024-3205(00)00489-6)

Mazik PM, Simco BA \& Parker NC 1991 Influence of water hardness and salts on survival and physiological characteristics of striped bass during and after transport. Transactions of the American Fisheries Society 120 121-126. (doi:10. 1577/1548-8659(1991)120<0121:IOWHAS > 2.3.CO;2)

Mazon AF, Nolan DT, Lock RAC, Fernandes MN \& Wendelaar Bonga SE 2004 A short-term in vitro gill culture system to study the effects of toxic (copper) and non-toxic (cortisol) stressors on the rainbow trout, Oncorhynchus mykiss (Walbaum). Toxicology In Vitro 18 691-701. (doi:10. 1016/j.tiv.2004.03.008)

McCormick SD 1990 Cortisol directly stimulates differentiation of chloride cells in tilapia opercular membrane. American Journal of Physiology. Regulatory, Integrative and Comparative Physiology 259 R857-R863.

McCormick SD, Dickhoff WW, Duston J, Nishioka RS \& Bern HA 1991 Developmental differences in the responsiveness of gill $\mathrm{Na}^{+}, \mathrm{K}^{+}$-ATPase to cortisol in salmonids. General and Comparative Endocrinology 84 308-317. (doi:10.1016/0016-6480(91)90054-A)

McCormick SD 2001 Endocrine control of osmoregulation in teleost fish. American Zoologist 41 781-794. (doi:10.1668/0003-1569(2001)041[0781: ECOOIT]2.0.CO;2)

McCormick SD \& Bern HA 1989 In vitro stimulation of $\mathrm{Na}^{+}-\mathrm{K}^{+}$-ATPase activity and ouabain binding by cortisol in coho salmon gill. American Journal of Physiology. Regulatory, Integrative and Comparative Physiology 256 R707-R715.

McCormick SD \& Bradshaw D 2006 Hormonal control of salt and water balance in vertebrates. General and Comparative Endocrinology 147 3-8 (Review). (doi:10.1016/j.ygcen.2005.12.009)

McCormick SD, Regish A, O’Dea MF \& Shrimpton JM 2008 Are we missing a mineralocorticoid in teleost fish? Effects of cortisol, deoxycorticosterone and aldosterone on osmoregulation, gill $\mathrm{Na}^{+}, \mathrm{K}^{+}$-ATPase activity and isoform mRNA levels in Atlantic salmon General and Comparative Endocrinology 157 35-40. (doi:10.1016/j.ygcen.2008.03.024)

Mommsen TP, Vijayan MM \& Moon TW 1999 Cortisol in teleosts: dynamics mechanisms of action, and metabolic regulation. Reviews in Fish Biology and Fisheries 9 211-268. (doi:10.1023/A:1008924418720)

Morgan JD, Sakamoto T, Grau EG \& Iwama GK 1997 Physiological and respiratory responses of the mozambique tilapia (Oreochromis mossambicus) to salinity acclimation. Comparative Biochemistry and Physiology. Part A, Physiology 117 391-398. (doi:10.1016/S0300-9629(96)00261-7)

Nilsen TO, Ebbesson LO, Madsen SS, McCormick SD, Andersson E, Björnsson BT, Prunet P \& Stefansson SO 2007 Differential expression of gill $\mathrm{Na}^{+}, \mathrm{K}^{+}$-ATPase alpha- and beta-subunits, $\mathrm{Na}^{+}, \mathrm{K}^{+}, 2 \mathrm{Cl}^{-}$cotransporter and CFTR anion channel in juvenile anadromous and landlocked Atlantic salmon Salmo salar. Journal of Experimental Biology 210 2885-2896. (doi:10.1242/jeb.002873)

Noga EJ, Kerby JH, King W, Aucoin DP \& Giesbrecht F 1994 Quantitative comparison of the stress response of striped bass (Morone saxatilis) and hybrid striped bass (Morone saxatilis x Morone chrysops and Morone saxatilis x Morone americana). American Journal of Veterinary Research 55 405-409.
Pelis RM \& McCormick SD 2001 Effects of growth hormone and cortisol on $\mathrm{Na}(+)-\mathrm{K}(+)-2 \mathrm{Cl}(-)$ cotransporter localization and abundance in the gills of Atlantic salmon. General and Comparative Endocrinology 124 134-143. (doi:10.1006/gcen.2001.7703)

Pfaffl MW 2001 A new mathematical model for relative quantification in realtime RT-PCR. Nucleic Acids Research 29 e45. (doi:10.1093/nar/29.9.e45)

Prunet P, Sturm A \& Milla S 2006 Multiple corticosteroid receptors in fish: from old ideas to new concepts. General and Comparative Endocrinology 147 17-23 (Review). (doi:10.1016/j.ygcen.2006.01.015)

Richards JG, Semple JW, Bystriansky JS \& Schulte PM $2003 \mathrm{Na}^{+} / \mathrm{K}^{+}$ATPase (alpha-isoform switching in gills of rainbow trout (Oncorhynchus mykiss) during salinity transfer. Journal of Experimental Biology 206 4475-4486. (doi:10.1242/jeb.00701)

Sakamoto T, Uchida K \& Yokota S 2001 Regulation of the ion-transporting mitochondrion-rich cell during adaptation of teleost fishes to different salinities. Zoological Science 18 1163-1174. (doi:10.2108/zsj.18.1163)

Scott GR, Richards JG, Forbush B, Isenring P \& Schulte PM 2004 Changes in gene expression in gills of the euryhaline killifish Fundulus heteroclitus after abrupt salinity transfer. American Journal of Physiology. Cell Physiology 287 C300-C309. (doi:10.1152/ajpcell.00054.2004)

Scott GR, Keir KR \& Schulte PM 2005 Effects of spironolactone and RU486 on gene expression and cell proliferation after freshwater transfer in the euryhaline killifish. Journal of Comparative Physiology. Part B 175 499-510. (doi:10.1007/s00360-005-0014-2)

Shaw JR, Gabor K, Hand E, Lankowski A, Durant L, Thibodeau R, Stanton CR, Barnaby R, Coutermarsh B, Karlson KH et al. 2007 Role of glucocorticoid receptor in acclimation of killifish (Fundulus heteroclitus) to seawater and effects of arsenic. American Journal of Physiology. Regulatory, Integrative and Comparative Physiology 292 R1052-R1060. (doi:10.1152/ ajpregu.00328.2006)

Shrimpton JM \& McCormick SD 1999 Responsiveness of gill $\mathrm{Na}^{+} / \mathrm{K}^{+}$ATPase to cortisol is related to gill corticosteroid receptor concentration in juvenile rainbow trout. Journal of Experimental Biology 202 987-995.

Sloman KA, Desforges PR \& Gilmour KM 2001 Evidence for a mineralocorticoid-like receptor linked to branchial chloride cell proliferation in freshwater rainbow trout. Journal of Experimental Biology 204 3953-3961.

Sturm A, Bury N, Dengreville L, Fagart J, Flouriot G, Rafestin-Oblin ME \& Prunet P 2005 11-Deoxycorticosterone is a potent agonist of the rainbow trout (Oncorhynchus mykiss) mineralocorticoid receptor. Endocrinology 146 47-55. (doi:10.1210/en.2004-0128)

Sunny F \& Oommen OV 2001 Rapid action of glucocorticoids on branchial ATPase activity in Oreochromis mossambicus: an in vivo and in vitro study. Comparative Biochemistry and Physiology. Part B, Biochemistry and Molecular Biology 130 323-330. (doi:10.1016/S1096-4959(01)00438-9)

Sunny F, Lakshmy PS \& Oommen OV 2002 Rapid action of cortisol and testosterone on lipogenic enzymes in a fresh water fish Oreochromis mossambicus: short-term in vivo and in vitro study. Comparative Biochemistry and Physiology. Part B, Biochemistry \& Molecular Biology 131 297-304. (doi:10. 1016/S1096-4959(02)00023-4)

Tang CH \& Lee TH 2007 The effect of environmental salinity on the protein expression of $\mathrm{Na}^{+} / \mathrm{K}^{+}$-ATPase, $\mathrm{Na}^{+} / \mathrm{K}^{+} / 2 \mathrm{Cl}(-)$ cotransporter, cystic fibrosis transmembrane conductance regulator, anion, exchanger 1 , and chloride channel 3 in gills of a euryhaline teleost, Tetraodon nigroviridis. Comparative Biochemistry and Physiology. Part A, Molecular \& Integrative Physiology 147 521-528. (doi:10.1016/j.cbpa.2007.01.679)

Tipsmark CK \& Madsen SS 2009 Distinct hormonal regulation of $\mathrm{Na}(+)$, $\mathrm{K}(+)$-ATPase genes in the gill of Atlantic salmon (Salmo salar L.). Journal of Endocrinology 203 301-310. (doi:10.1677/JOE-09-0281)

Tipsmark CK, Madsen SS, Seidelin M, Christensen AS, Cutler CP \& Cramb G 2002 Dynamics of $\mathrm{Na}^{+}, \mathrm{K}^{+}, 2 \mathrm{Cl}(-)$ cotransporter and $\mathrm{Na}^{+}, \mathrm{K}^{+}$-ATPase expression in the branchial epithelium of brown trout (Salmo trutta) and Atlantic salmon (Salmo salar). Journal of Experimental Zoology 293 106-118. (doi:10.1002/jez.10118)

Tipsmark CK, Madsen SS \& Borski RJ 2004 Effect of salinity on expression of branchial ion transporters in striped bass (Morone saxatilis). Journal of Experimental Zoology. Part A, Comparative Experimental Biology 301 979-991. (doi:10.1002/jez.a.119) 
Tipsmark CK, Luckenbach JA, Madsen SS \& Borski RJ 2007 IGF-I and branchial IGF receptor expression and localization during salinity acclimation in striped bass. American Journal of Physiology. Regulatory, Integrative and Comparative Physiology 292 R535-R543. (doi:10.1152/ajpregu.00915.2005)

Uchida K, Kaneko T, Miyazaki H, Hasegawa S \& Hirano T 2000 Excellent salinity tolerance of Mozambique tilapia (Oreochromis mossambicus): elevated chloride cell activity in the branchial and opercular epithelia of the fish adapted to concentrated seawater. Zoological Science 17 149-160. (doi:10.2108/zsj.17.149)

Wang PJ, Lin CH, Hwang LY, Huang CL, Lee TH \& Hwang PP 2009

Differential responses in gills of euryhaline tilapia, Oreochromis mossambicus, to various hyperosmotic shocks. Comparative Biochemistry and Physiology Part A, Molecular and Integrative Physiology 152 544-551. (doi:10.1016/ j.cbpa.2008.12.012)

Received in final form 11 January 2011

Accepted 31 January 2011

Made available online as an Accepted Preprint 31 January 2011 